\title{
Follow up the antibodies titer against Newcastle disease virus in broiler breeders using ELISA test
}

\author{
F.A. Isihak ${ }^{1}$, S.M. Hassan ${ }^{2}$, B.Z. Shaker ${ }^{3}$ and Y.A. Saleh ${ }^{4}$ \\ ${ }^{1}$ Department of Microbiology, College of Veterinary Medicine, University of Mosul, Mosul, \\ ${ }^{2}$ Department of Pathology and Poultry Diseases, College of Veterinary Medicine, Al Qasim Green University, Babylon, \\ ${ }^{3,4}$ Technical Sector, Kosar Company for Agriculture and Poultry, Erbil, Iraq \\ Email: ${ }^{1}$ fanar1976@yahoo.com, ${ }^{2}$ sm.hassan04@gmail.com, ${ }^{3}$ balqees@kosarcompany.com, ${ }^{4}$ tech@kosarcompa
}

(Received July 16, 2019; Accepted September 24, 2019; Available online June 11, 2020)

\begin{abstract}
The study period carried out from 25 April 2018 till 21 May 2019 through the rearing and production period including totally of 24000 birds (20800 females, 3200 males). The number of tested blood samples was 452 divided to 255 samples at the rearing period, 143 samples at the production period and 54 samples of offspring. The results of antibodies titer in the sera of non-vaccinated broiler breeders obtained by ELISA showed the maternal derived antibodies titer for 28 samples at $0-5$ week/day of age was $5716 \pm 612.7$, this titer decreased gradually at 3-1 week/day age till to $1075 \pm 234$ ) Then the titer was elevated increasingly after vaccination with both live attenuated and inactivated vaccines and reach to peak $37512 \pm 2049.4$ at 20-1 week/day age. Whereas the bimodal graduation of antibodies titer showed at production period till to end of study. The mean of maternally antibodies titer in the tested sera of the offspring chicks $0-1$ week/day that hatched from parent flocks at 32,39 and 48 weeks of age was $9012 \pm 872.4,6591 \pm 368.1$ and $4831 \pm 982.7$ respectively. Thus, we concluded the repetitive vaccination of broiler breeders flock with live vaccine as well as inactivated vaccine is very necessary in endemic areas and ELISA is a good serological test for following, checking and monitoring of immune status of poultry flocks periodically.
\end{abstract}

Keywords: Newcastle Disease, Antibodies, ELISA, Broiler Breeders, Vaccine

DOI: 10.33899/ijvs.2019.125931.1189, (C) 2020, College of Veterinary Medicine, University of Mosul.

This is an open access article under the CC BY 4.0 license (http://creativecommons.org/licenses/by/4.0/).

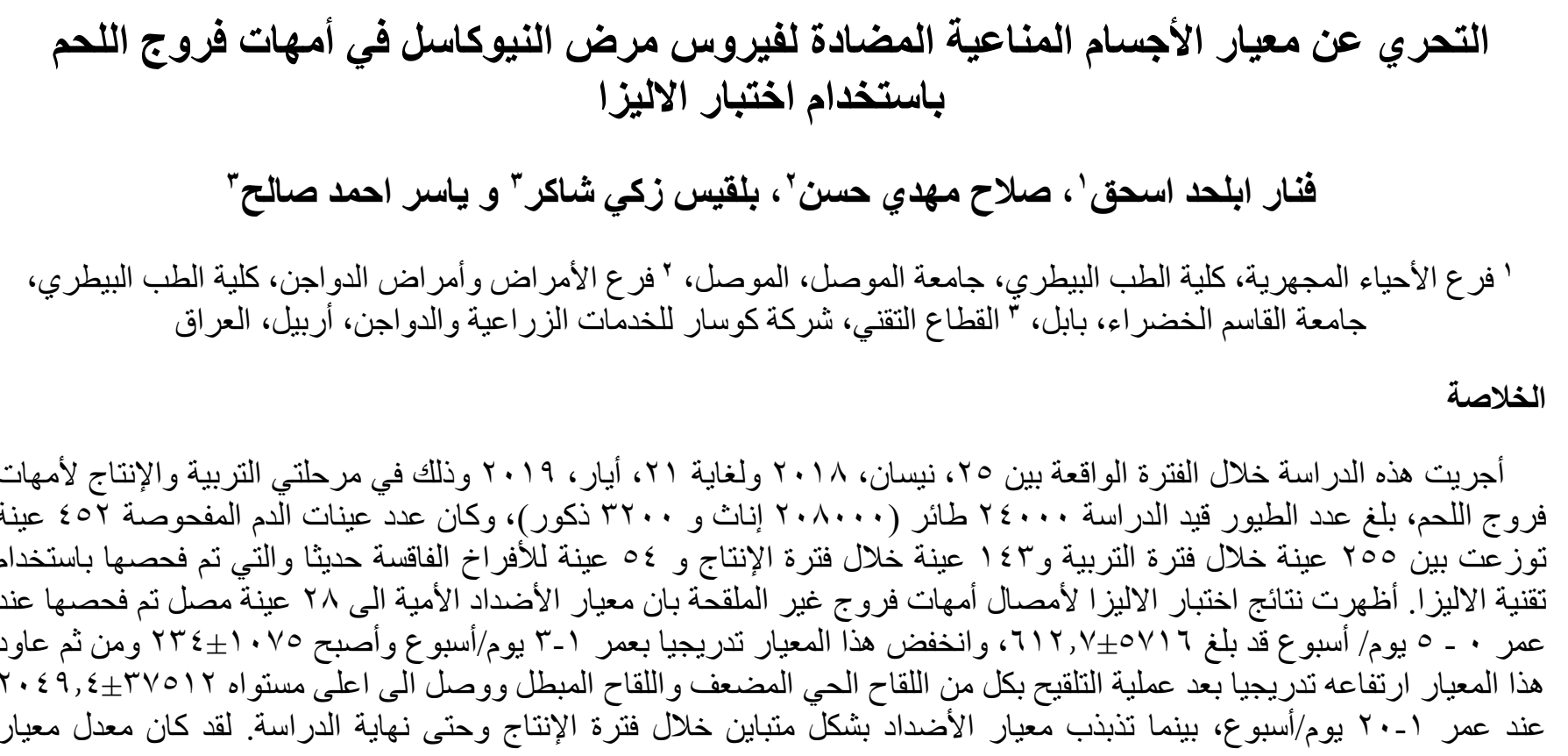




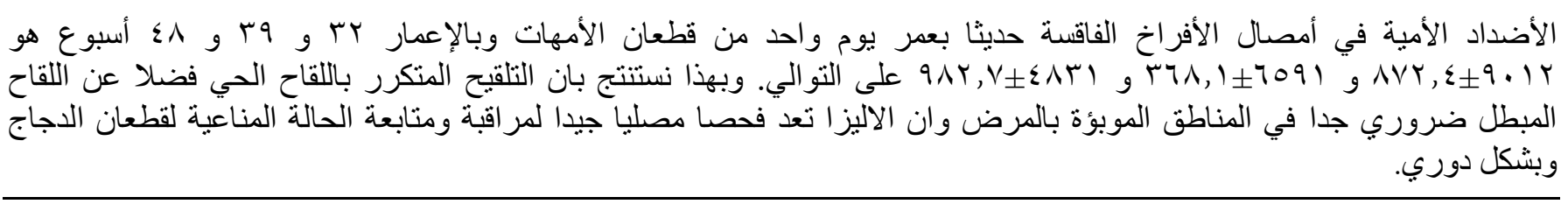

\section{Introduction}

Newcastle Disease (ND) considered as one of the most crucial viral diseases causing severe illness of poultry globally (1). It is an economically important disease and one of main hazard for the poultry industry worldwide (2). The causative agent is Newcastle Disease Virus (NDV) which is belongs to the avian paramyxovirus type-1 (APMV-1) serotype, genus Avulavirus and family Paramyxoviridae (3). The ND is a highly contagious disease in numerous species of domestic, wild and exotic birds that depending on its tropism, it is characterized by marked distinctions in morbidity, mortality rate, symptoms and lesions $(4,5)$.

The clinico-morphological signs have a discrete viscerotropic or neurotropic character (5). Birds at any age are susceptible to this disease depending on their pathogenicity; the several known strains are classified as lentogenic, mesogenic and velogenic (6). Different vaccines are being used to protect and control of ND. Presently, several live attenuated and inactivated vaccines against ND are existing nearby the world $(7,8)$ and the vaccines were entirely active against Newcastle disease virus (9).

Vaccination programs of chickens against Newcastle Disease are regularly applied throughout the world. The results obtained by (10) concluded to using efficient vaccination programs to avoid harms associated with Newcastle disease virus. Ideally, vaccination process against NDV would result an immune reaction against infection and replication of the field virus.

The aim of this study is detection and follows up the antibodies titer in broiler breeder flock using ELISA test through the rearing and production period with standard management, feeding and vaccination programs guides.

\section{Materials and methods}

\section{Birds}

Totally of 24000 birds ROSS breed chickens (20800 females, 3200 males) included 4 poultry houses. The study period carried out from 25 April 2018 till 21 May 2019 in Taq Taq poultry project (Erbil/Iraq) including the rearing and production period from 1-56 weeks of age.

The vaccination program, number of blood samples, age (week/day), bleeding date of broiler breeders and offspring were described in tables 1-4.
In addition to $\mathrm{ND}$ vaccination program other vaccines were used including IBD, IB, Avian Influenza (H9N2), EDS and MG.

\section{Vaccination program}

The vaccination program of the birds as describe in table 1 .

Table 1: Vaccination program of birds

\begin{tabular}{|c|c|c|c|}
\hline Vaccine & Doses/vial & Method & Age \\
\hline $\begin{array}{l}\text { Nobilis }{ }^{\circledR} \text { ND } \\
\text { Clone30 strain }\end{array}$ & 2500 & spraying & 10-day age \\
\hline $\begin{array}{l}\text { Nobilis }{ }^{\circledR} \text { ND La } \\
\text { Sota strain }\end{array}$ & 2500 & spraying & $\begin{array}{c}\text { every } 10 \\
\text { days }\end{array}$ \\
\hline $\begin{array}{l}\text { Nobilis }^{\circledR} \text { ND } \\
\text { Clone } 30 \text { strain }\end{array}$ & 500 & $\begin{array}{c}\text { SC or } \\
\text { IM }\end{array}$ & $\begin{array}{c}12 \text { day ( } 1^{\text {st }} \\
\text { dose) }\end{array}$ \\
\hline $\begin{array}{l}\text { Nobilis }^{\circledR}+\text { ND } \\
\text { Clone } 30 \text { strain }\end{array}$ & 500 & $\begin{array}{l}\text { SC or } \\
\text { IM }\end{array}$ & $\begin{array}{l}17 \text { weeks } \\
\left(2^{\text {nd }} \text { dose }\right)\end{array}$ \\
\hline
\end{tabular}

Note: all the above vaccine is produced by Intervet International B.V. (Holland).

\section{Blood samples}

A total of 452 blood samples 1-2 $\mathrm{ml}$ were collected via the wing vein of birds randomly, 255 samples at the rearing period 1-24 weeks and 143 samples at production period 25-56 weeks (Tables 2 and 3), While 54 blood samples were collected separately from 3 groups 18 samples for each group of newly hatched offspring that produced from fertile eggs laid by this flock at 32, 39 and 48 weeks age.

The serum from each sample was separated by centrifugation $1500 \mathrm{rpm} /$ for 15 minutes and stored in properly labeled vials at $-20^{\circ} \mathrm{C}$ for further processing (ELISA test was done in Rasty lab/Kosar company for agriculture and poultry/Erbil//raq).

\section{Indirect ELISA test}

The samples of Serum were tested for detection of antibodies titer against NDV by commercial Enzyme Linked Immuno-Sorbent Assay Kit (ELISA) for ND (SYNBIOTICS/ ProFLOK /Zoetis/USA) according to the recommended technique by the producer. The mean of ELISA antibodies titer statistically analyzed and carried out using SPSS version 19.0 (11). 
Table 2: Number of blood samples, age and bleeding date of birds at the rearing period

\begin{tabular}{cccc}
\hline & $\begin{array}{c}\text { Number of } \\
\text { samples }\end{array}$ & $\begin{array}{c}\text { Age } \\
\text { (week/day) }\end{array}$ & $\begin{array}{c}\text { Bleeding } \\
\text { date }\end{array}$ \\
\hline & 28 & $0-5$ & $30 / 4 / 2018$ \\
& 20 & $3-1$ & $17 / 5 / 2018$ \\
& 18 & $4-1$ & $24 / 5 / 2018$ \\
& 18 & $5-1$ & $02 / 6 / 2018$ \\
Rearing & 18 & $6-1$ & $09 / 7 / 2108$ \\
Period & 18 & $7-1$ & $16 / 7 / 2018$ \\
& 15 & $8-6$ & $28 / 7 / 2018$ \\
& 18 & $10-5$ & $10 / 8 / 2018$ \\
& 18 & $12-1$ & $20 / 8 / 2018$ \\
& 18 & $14-1$ & $04 / 9 / 2018$ \\
& 18 & $16-4$ & $21 / 9 / 2018$ \\
& 18 & $20-1$ & $15 / 10 / 2018$ \\
Total & 255 & $24-0$ & $12 / 11 / 2018$ \\
\hline
\end{tabular}

Table 3: Number of blood samples, age and bleed date of birds at the production period

\begin{tabular}{cccc}
\hline & $\begin{array}{c}\text { Number of } \\
\text { samples }\end{array}$ & $\begin{array}{c}\text { Age } \\
\text { (week/day) }\end{array}$ & $\begin{array}{c}\text { Bleeding } \\
\text { date }\end{array}$ \\
\hline & 18 & $25-5$ & $24 / 11 / 2018$ \\
& 14 & $29-1$ & $17 / 12 / 2018$ \\
Production & 23 & $32-1$ & $07 / 01 / 2019$ \\
Period & 18 & $33-6$ & $19 / 01 / 2019$ \\
& 18 & $39-2$ & $27 / 02 / 2019$ \\
& 18 & $43-4$ & $26 / 03 / 2019$ \\
& 16 & $48-0$ & $27 / 04 / 2019$ \\
& 18 & $56-0$ & $21 / 05 / 2019$ \\
\hline total & 143 & & \\
\hline
\end{tabular}

Table 4: Number of blood samples, age and bleed date of the offspring

\begin{tabular}{lccc}
\hline & $\begin{array}{c}\text { Number of } \\
\text { samples }\end{array}$ & $\begin{array}{c}\text { Age } \\
\text { (week/day) }\end{array}$ & $\begin{array}{c}\text { Bleeding } \\
\text { date }\end{array}$ \\
\hline Production & 18 & $0-1$ & $1 / 2 / 2019$ \\
Period & 18 & $0-1$ & $23 / 3 / 2019$ \\
& 18 & $0-1$ & $20 / 5 / 2019$ \\
\hline Total & 54 & & \\
\hline
\end{tabular}

\section{Results}

The results of table 5 showed the antibodies titer in the sera of birds obtained by ELISA. The maternal derived antibodies (MDA) titer for 28 samples at $0-5$ week/day of age was $5716 \pm 612.7$. This titer progressively decreased at 3-1 week/day age till to $1075 \pm 234$. Then this titer was elevated gradually after immunization with both live attenuated and inactivated vaccines and reach to peak $37512 \pm 2049.4$ at 20-1 week/day age. The antibodies titer at production period showed bimodal graduation and was $21605 \pm 979.6,9260 \pm 456.9,5155 \pm 337.6$ at $32-1,39-2$ and 48-0 weeks/day respectively (Table 6). While the antibodies titer in the tested sera of the offspring showed maximum level 9012 at $0-1$ week/day in these chicks that hatched from parent flocks with 32 weeks age and decreased to 6591 and 4831 in offspring 0-1 week/day hatched from same parent flock with 39 and 48 weeks of age respectively (Table 7).

Table 5: Antibodies titer against NDV measured by ELISA in the sera of birds at the rearing period with $\mathrm{CV}$

\begin{tabular}{ccc}
\hline $\begin{array}{c}\text { Age } \\
\text { (week/day) }\end{array}$ & $\begin{array}{c}\text { Antibodies titer } \\
(\text { mean } \pm \text { SE) }\end{array}$ & $\begin{array}{c}\text { CV } \\
(\%)\end{array}$ \\
\hline $0-5$ & $5716 \pm 612.7$ & 39.73 \\
$3-1$ & $1075 \pm 234$ & 65.94 \\
$4-1$ & $2764 \pm 645.7$ & 74.82 \\
$5-1$ & $3946 \pm 972.8$ & 80.82 \\
$6-1$ & $7283 \pm 1024$ & 44.1 \\
$7-1$ & $8244 \pm 1052.8$ & 40.27 \\
$8-6$ & $14621 \pm 2021.1$ & 38.32 \\
$10-5$ & $8679 \pm 774.6$ & 19.2 \\
$12-1$ & $13335 \pm 1067$ & 23.05 \\
$14-1$ & $12469 \pm 1229.4$ & 29.5 \\
$16-4$ & $17048 \pm 1796.2$ & 32.22 \\
$20-1$ & $37512 \pm 2049.4$ & 15.32 \\
$24-0$ & $14780 \pm 802.1$ & 16.47 \\
\hline
\end{tabular}

Table 6: Antibodies titer against NDV measured by ELISA in the sera of birds at the production period with $\mathrm{CV}$

\begin{tabular}{ccc}
\hline $\begin{array}{c}\text { Age } \\
\text { (week/day) }\end{array}$ & $\begin{array}{c}\text { Antibodies titer } \\
(\text { mean } \pm \text { SE) }\end{array}$ & $\begin{array}{c}\text { CV } \\
(\%)\end{array}$ \\
\hline $25-5$ & $21009 \pm 1482.8$ & 19.99 \\
$29-1$ & $14758 \pm 801.6$ & 13.98 \\
$32-1$ & $21605 \pm 979.6$ & 15.08 \\
$33-6$ & $21930 \pm 1009$ & 13.41 \\
$39-2$ & $9260 \pm 456.9$ & 14.42 \\
$43-4$ & $12600 \pm 1868.2$ & 45.2 \\
$48-0$ & $5155 \pm 337.6$ & 19.06 \\
$56-0$ & $11126 \pm 452.4$ & 11.66 \\
\hline
\end{tabular}

\section{Discussion}

The vaccination process of poultry flocks against ND provides a good immune status against virulent NDV (12), and there was different kinds and brands of vaccines available in Iraqi as well as world market for controlling of ND including live attenuated and inactivated vaccines, and it is acknowledged that live attenuated vaccines are easy to use, low charge and provide modest to good immune 
response. The ND is endemic in Iraq (13), therefore this disease is determined as one of the limiting aspects in poultry production and the using of vaccines in poultry industry is traditionally intended for preventing or diminishing the rise of clinical illness and to avoid epizootics (14).

Table 7: Antibodies titer against NDV measured by ELISA in the sera of offspring with $\mathrm{CV}$

\begin{tabular}{lcc}
\hline \multicolumn{1}{c}{$\begin{array}{c}\text { Age } \\
\text { (week/day) }\end{array}$} & $\begin{array}{c}\text { Antibodies titer } \\
\text { (mean } \pm \text { SE) }\end{array}$ & $\begin{array}{c}\text { CV } \\
(\%)\end{array}$ \\
\hline $\begin{array}{l}\text { Offspring from parent } \\
\text { flock at 32 weeks }\end{array}$ & $9012 \pm 872.4^{\mathrm{a}}$ & 13.4 \\
$\begin{array}{l}\text { Offspring from parent } \\
\text { flock at 39 weeks }\end{array}$ & $6591 \pm 368.1^{\mathrm{b}}$ & 23.86 \\
$\begin{array}{l}\text { Offspring from parent } \\
\text { flock at 48 weeks }\end{array}$ & $4831 \pm 982.7^{\mathrm{c}}$ & 24.61 \\
\hline
\end{tabular}

Letters that different in column means presence of significant differences at $\mathrm{P}<0.05$.

The reasons of regular vaccination programs for broiler breeders in this study are usually depend on the routine usage of numerous dosages of lentogenic live attenuated vaccine followed by inactivated vaccine before the onset of lay. While the live mesogenic vaccines tend to be spent only in countries where velogenic NDV is extensive and maintenance (15). The broiler breeders' chicks from ND vaccinated parents (ROSS 308) usually confined high amount of maternally derived ND antibodies at 1 day old and then dropped progressively with age. It was noticed that maternally derived ND antibody declined at negligible level or less at 28 day of age (16). The rate of declination of maternally derived antibody was around $1 / 2$ by every seven days old. This obtaining is partly in agreement with the finding of (17).

The titer of antibodies was increased after the administration of birds with live attenuated ND vaccine by programmed interval spraying method and then revaccinated with an oily emulsion inactivated vaccine for long period (18). The use of inactivated vaccine against ND in broiler breeder is required and its should be used earlier than point of laying period. Also, for avoidance the loss of egg trait, egg production, hatching and to achieve extreme level of antibodies titer in broiler breeder flocks (19). In this study the titer of antibodies was elevated suddenly and reach to high level $37512 \pm 2049.4$ at $20-1$ week/day of age and this elevation of titer was due to the rolling or circulating of field virus within the flock with on obvious clinical signs (subclinical infection) or may have donated to the fact that existing vaccines and vaccination programs are not maximally efficient in avoiding the transmission of infection (20) and it was described that vaccination campaigns of poultry against ND can only protect the birds from the more severe consequence of highly pathogenic (velogenic) NDV, but not from infection and replication of the virulent strains of virus (21). Despite broad use of ND vaccines but the disease is quite recorded sometimes as subclinical infections that may be considered the cause of raise of antibodies titer in this pattern. In the other hand, the unstable or bimodal form of the antibody titer may be due to considerable deference in the individual antibodies of protected birds representing potential difference in the levels of defense post immunization. Certainly, researches reviewed that infection, shedding, and spreading of virulent NDV in previously vaccinated flocks may appear without overt symptoms of illness (22). The maternally derived antibodies against NDV provides protection for young chicks and the amount of NDV particular antibodies transferred from the hen to the offspring it is directly correlated to titer of these antibodies in hen (23). High titer of antibodies in offspring hatched from parent flock at 32 weeks age is due to the inactivated oily emulsion vaccines which have been successfully used in vaccination program through the rearing period (16). The results also revealed drop of antibodies titer in offspring hatched from same flock at 39 and 48 weeks is due to declining the immunogenic activity of oil emulsion vaccine in the stimulation of immune system with progress the age of parent stock (24).

\section{Conclusions}

we concluded the repetitive vaccination of broiler breeders flock with live attenuated associated with inactivated vaccine is very important in endemic areas to prevent or minimize the infections with velogenic strains of field virus and ELISA is one of active and suitable diagnostic and serological test for following, checking and monitoring of immune status of poultry farms.

\section{Acknowledgment}

This study work was supported by the Kosar Company for Agriculture and Poultry and Taq Taq poultry project of broiler breeders for enabling the conduct of the field work.

\section{Conflict of Interest}

The authors declare that there is no conflict of interest.

\section{References}

1. Orsi MAL, Doretto J, Camillo SCA, Reischak D, Ribeiro SAM. Prevalence of Newcastle disease virus in broiler chickens (Gallus gallus) in Brazil. Braz J Microbiol. 2010;41:349-357. 10.1590/S151783822010000200014

2. Abdisa T, Tagesu T. Review on Newcastle Disease of Poultry and its Public Health Importance. J Vet Sci Technol. 2017;8:3. DOI: $10.4262 / 2157-7579.1000441$ 
3. Thomazelli LM, De Ara'ujo J, Fabrizio T. Novel avian paramyxovirus (APMV-15) isolated from a migratory bird in South America. PLoS ONE. 2017;12(5):e0177214. 10.1155/2018/7278459

4. Choi KS, Lee EK, Jeon WJ, Kwon JH. Antigenic and immunogenic investigation of the virulence motif of the Newcastle disease virus fusion protein. J Vet Sci. 2010;1:205-211. 10.4142/jvs.2010.11.3.205

5. Mustafa NG. Effects of Newcastle disease vaccine on the liver and antioxidant enzymes of chicks. Iraqi J Vet Sci. 2018:243-247.DOI. 10.33899/ijvs. 2019. 153856

6. Alexander DJ. Newcastle disease, other avian paramyxoviruses, and pneumovirus infection. In: Saif YM, Barnes HJ, Glisson JR (editors). Disease of poultry. $12^{\text {th }}$ ed. Oxford: Blackwell; 2003. 75-100 p.

7. Bello MB, Yusoff K, Ideris A, Hair-Bejo M, Peeters BPH, Omaral A. Diagnostic and vaccination approaches for Newcastle disease virus in poultry: The current and emerging perspectives. BioMed Res Inter. 2018;7278459:1-18 10.1155/2018/7278459

8. Shim JB, So HH, Won HK, Mo IP. Characterization of avian paramyxovirus type 1 from migratory wild birds and chickens. J. Avian Pathol. 2011;40:565-572. 10.1080/03079457.2011.616187

9. Xiao S, Paldurai A, Nayak B, Mirande A, Collins PL, Samal SK. Complete genome sequence of a highly virulent Newcastle disease virus currently circulating in Mexico. Genome Announ. 2013;1:101128. 10.1128/genomeA.00177-12

10. Dimitrov KM, Afonso CL, Yu Q, Miller PJ. Newcastle disease vaccines A solved problem or a continuous challenge ?.Vet Microbiol. 2017;1:126-136. doi.org/10.1016/j.vetmic.2016.12.019

11. Absalón AE, Cortés-Espinosa DV, Lucio E, Miller PJ, Afonso CL. Epidemiology, control, and prevention of Newcastle disease in endemic regions: Latin America. Trop Anim Health Prod. 2019; 51(5): 1033-1048. doi: 10.1007/s11250-019-01843-Z

12. Steel RGD, Torrie JH, Dickey DA. Principles and procedures of statistics: A Biometrical approach. $3^{\text {rd }}$ ed. New York: McGraw-Hill Book Co; 1997. 350-386 p. 10.4236/blr.2014.54024

13. Kapczynski DR, King DJ. Protection of chickens against overt clinical disease and determination of viral shedding following vaccination with commercially available Newcastle disease virus vaccines upon challenge with highly virulent virus from the California 2002 exotic Newcastle disease outbreak. Vaccine. 2005.23:3424-3433. 10.1016/j.vaccine. 2005.01 .140

14. Ahmed AI, Odisho SM. Isolation and identification and pathotyping of Newcastle disease viruses from naturally infected chicken in Irqai Kurdistan region. Iraqi J Agri Sci. 2018;1(49):132-141.
15. Bello MB, Yusoff K, Ideris A, Hair-Bejo M, Peeters BPN, Omar A. Diagnostic and Vaccination Approaches for Newcastle Disease Virus in Poultry: The Current and Emerging Perspectives. BioMed Res Inter. 2018:7278459. https://doi.org/10.1155/2018/7278459.

16. OIE. Newcastle disease: Manual of diagnostic tests and vaccines for terrestrial animals (mammals, birds and bees). 2008;1:576-589.

17. Ali MZ, Hasan B. Follow up of maternally derived antibodies titer against economically important viral diseases of chicken. Poult Sci J. 2018;6(2):149-154. 10.22069/psj.2018.15213.1340

18. Rahman MM, Bari ASM, Giasuddin MR, Alam J, Sil GC, Rahman MM. Evaluation of maternal and humoral immunity against Newcastle disease virus in chicken. Inter J Poult Sci. 2002;1:161-163. 10.3932/ijps.2002.161.163

19. Mebrahtu1 K, Teshale S, Esatu W, Habte T, Gelaye E. Evaluation of spray and oral delivery of Newcastle disease I2 vaccine in chicken reared by smallholder farmers in central Ethiopia. BMC Vet Res. 2018;14:48. 10.1186/s12917-018-1355-X

20. Samad MA, Kafi MA, Amin MM, Gani MO. Investigation on the immunity level of breeder flocks following vaccination with Newcastle disease virus vaccine. Bangladesh J Vet Med. 2008;5:1518. DOI.10.3329.bjvm.v5i1.1303

21. Miller PJ, Decanini EL, Afonso CL. Newcastle disease: evolution of genotypes and the related diagnostic challenges. Infect Genet Evol. 2010;10:26-35. 10.1016/j.meegid.2009.09.012

22. Miller PJ, King DJ, Alfonso CL, Suarez DL. Antigenic differences among Newcastle disease virus strains of different genotypes used in vaccine formulation affect viral shedding after a virulent challenge. Vaccine. 10.1016/j.vaccine.2007.07.017

23. Van Boven M, Bouma A, Fabri THF, Katsma E, Hartog L, Koch G. Herd immunity to Newcastle disease virus in poultry by vaccination. Avian Pathol .2008.37:15. 10.1080/03079450701772391

24. Hamal KR, Burgess SC, Pevzner IY, Erf GF. Maternal Antibody transfer from dams to their egg yolks, egg whites, and chicks in meat lines of chickens. Poult Sci. 2006;85:1364-1372. $10.1093 / \mathrm{ps} / 85.8 .1364$

25. Alexander DJ, Jones RC. Newcastle Disease. In: Jordan FTW (editor). Poultry diseases. $5^{\text {th }}$ ed. New York: WB Sanders; 2001. 257-272 p 